Received: 22-03-2018. Accepted: 29-11-2018. Published: 26-12-2018

\title{
Indonesian Capital Market Reaction Toward November, 4th 2016 Demonstration in Jakarta
}

\author{
Bambang Widagdo ${ }^{1}$, Novita Ratna Satiti ${ }^{2}$
}

\author{
Faculty of Economics and Business, Universitas Muhammadiyah Malang, Indonesia ${ }^{12}$
}

\begin{abstract}
This research is a case study that aims to find out whether there is empirical evidence of Indonesia capital market reaction to one of the domestic political events, namely Demonstration 4 November 2016 by using Trading Activity Volume and Abnormal Return. The population in this research are stocks that are included in LQ45 Index in Indonesia Stock Exchange, and the data used in this research is secondary data consist of daily stock price, daily stock trading volume, and daily stock price index during the previous 30 days, one day on Time, and 30 days after the event. The statistical tool used to test the hypothesis is the t-test and the Wilcoxon Signed Rank test. The result of calculation of variance analysis shows that there is a significant difference between Stock Trading Activity Volume at the time before, during and after demo 4 November 2016. Trading Stock Activity Volume increased but not significant from process before demo November 4th to process demo November 4th, but at the demo of November 4th to the condition after the demo of November 4th has increased significantly. ANOVA test results show that there is a significant difference between Abnormal Return Shares at the time before, during and after the demo of November 4th. That Abnormal Return Shares decreased significantly from the process before the demo November 4th to process demo 4 November 4th and Abnormal Return Shares When the demo of November 4th to the condition after the demo of November 4th also experienced a significant decrease. It can be said there is any reaction in the stock market due to the demonstration.
\end{abstract}

Keywords: Capital market; demonstration november 4th; trading activity volume; abnormal returns

\section{Introduction}

Researchers often apply event study to observe the impacts of an event on an object, such as financial activity that is easily subject to change, depending on the situation and obtained information. An event or phenomenon may affect businessmen's policies or plans. Such events are like disaster, terrorist attack or financial crisis. In this study, capital market is the object influencing the event. As an example, investor activities in the capital market require information as one significant element. By having it, investors can have a conception risk and expected return of securities in order to determine investment decisions and strategies to obtain the maximum rate of return even though whether or not an event will occur.

Sources of information that can affect the capital market are not only come from the financial environment. Basically, non-financial environment also contains information, so it cannot be separated from the capital market. Suryawijaya and Setiawan (2006) state that the more important role of the stock market in economic activities, the more sensitive it is to the surrounding events, whether they are or not directly related to the financial events. Political events are one part of the non-financial environment that can affect the condition of the capital market, since the dynamics of the political situation are basically also related to the financial stability of a country (Alkaff, 2010).

Further, numerous political events such as elections, presidential change, or political unrest, tend to have a response from market participants. It happens because these political events can have a positive or negative impact on the market stability that lead the investors to do transactions in the capital market. Political stability followed by the financial stability conditions will make investors feel safe to invest their funds in the market. Therefore, investors will generally put expectations on every occurring political event while their expectations will be reflected in price fluctuations or trading stock activity in the market.

The demonstration on November, 4th 2016 was one of the political events in Indonesia which is quite appealing to be reviewed. It was an action initiated by a number of Islamic mass organizations in Jakarta and its surrounding areas. It was a demonstration attended by 200,000 people and motivated by the alleged blasphemy committed by the Governor of Jakarta, Basuki Tjahaja Purnama in one of the interviews with the journalists. The event was predicted to steal the attention of the market participants, considering Jakarta is the capital of the state as well as the center of the frenzied economic activity in Indonesia. A large

\footnotetext{
1 bwidagdo@umm.ac.id

2 satiti.umm@gmail.com
} 
number of industrial areas, issuers and companies securities are headquartered in Jakarta, as well as investors and traders who are mostly domiciled in Jakarta, so that Indonesia capital market investment activity tends to be centralized in the city.

Political issues that occur in Jakarta will get the spotlight from the market participants. The riot possibility during the demonstration took place to make the investors put expectations especially related to the city's financial progress. Based on these arguments, the demonstration is considered potential to generate reaction from the market participants in the stock exchange, whether it will make a change in trading volume, price, and stock returns, especially for leading stocks that are liquid and have a high market capitalization. The capital market reaction to the information in an event can be measured by using the return as the price change value or by using the abnormal return that differentiate the actual return and the expected return of the investor (Jogiyanto, 2003).

In addition to using abnormal return, market reaction to information can also be seen through the parameter of trading volume activity in the market). Suryawijaya and Setiawan (Wardani, 2004) state that an increase in trading volume is a form of capital market reaction. It can be inferred into two intentions. If the increased trading volume is due to increased demand, it indicates that the event is a fine intention for the market participants, while if an increase in trading volume is the result of an increase in sales, then it could be inferred that the event is a bad news.

Based on the explanation above, this research will discuss: 1) Is there any reaction in Indonesian Stock Market toward November, 4th 2016 demonstration? 2) Is there any significant positive average abnormal return in the November, 4th 2016 demonstration? 3) Is there a significant difference on the average stock abnormal returns on before, during and after the period of November, 4th 2016 demonstration? 4) Is there any significant difference between the average stock trading volume activity on before, during and after the period of November, 4th 2016 demonstration?

\section{Literature Review}

The concept of efficient capital markets has become a remarkable topic to examine since it is a basic concept that can help understanding how the actual price mechanisms occurred in the market. For the financial sector, efficient market concept is more being emphasized on the information aspect. The relationship between the securities value and information is the key to measure efficient markets. According to Jogiyanto (2003), if the market reacts quickly and accurately to achieve a new equilibrium price that fully reflects the available information, then such market conditions are called efficient markets.

Event study is a research that studies the market reaction to an event or published information. MacKinley (1997) defines event study as a research methodology that uses financial market data to measure the impact of an event that is specific to a firm's value. In detail, it is usually reflected in its stock value and transaction volume. Its purpose is to examine the content information of an announcement. If the announcement contains information, it is expected that the market will react when it is already received by the market (Jogiyanto, 2003).

Compared to the economic events study, event study is still relatively small subject. It aims to test the market reaction to political events. However, event study indicates the link between stock price changes and events or information that are not directly related to economic activity showing an increasingly integrated role of the capital market in community social life (Suryawijaya and Setiawan, 2006). Capital markets can positively or negatively react to a political event.

For example, Rahayu's study (2007) shows positive reaction of the capital market to political events. She examined the capital market reaction to the reshuffle of Kabinet Indonesia Bersatu, as well as market reaction to the event of DKI Jakarta Second Round Governor Election in 2012. The result showed capital market reacting positive to the event on three trading days, indicated by the emergence of average abnormal return is positive and significant. Meanwhile, Meidawati and Harimawan's study (2004) proves a significant difference in the average value of trading volume activity during before and after the period of the political event. They conducted an event study on the 2004 Legislative Election, which examined the reaction of the capital market toward the political event of Election Result Announcement of DKI Jakarta on August, 16th 2007.

Other research by Chau, F., Deesomsak, R., \& Wang, J. (2014) show the impact of political uncertainty caused by the civil uprisings in the Arab World i.e., "Arab Spring" on the volatility of major stock markets in the MENA region. Our main findings are as follows. First, by distinguishing between conventional and Islamic stock market indices, we find that these two groups of investments react heterogeneously to the recent political turmoil. Specifically, we document a significant increase in the volatility of Islamic indices during the period of political unrests whereas the uprisings have had little or no significant effect on the volatility in conventional markets. 
Based on the results of the following studies, it may be stated that the Indonesian capital market is more sensitive to non-economic events and can react to political events, which is shown by significant differences in abnormal returns as well as trading volume activity around the date of the event. Thus, the hypothesis in this study can be shown as follows:

H1: There is any reaction in Indonesian Stock Market toward November, 4th 2016 demonstration

$\mathrm{H} 2$ : There is abnormal return and a significant positive Volume Activity trading movement around the date of November, 4th 2016 demonstration.

$\mathrm{H} 3$ : There is a significant difference on the average stock abnormal returns on before, during and after the period of November, 4th 2016 demonstration.

$\mathrm{H} 4$ : There is a significant difference between the average stock trading volume activity on before, during and after the period of November, 4th 2016 demonstration.

The November, 4th 2016 demonstration on capital market is staged in ten phases: Phase 1 defines the event of interest that refers to the new information available in the market related to event. Phase 2 forms a theory that provides a financial response explanation to the new information. Phase 3 identifies the set of companies experiencing the event and identifies the event dates; in other words, it performs selection criteria to insert a company whether it is included in the research sample. Companies included in the sample criteria are companies indexed LQ45 in the stock market.

Phase 4 selects a suitable window event and justifying the distance if it exceeds more than two days. In this case, it identifies the period in which the stock prices of the companies involved with the observed event. In addition, the observation period of this study is 30 days of the pre-event and 30 days post-event. The timeline series of this event study can be seen in Figure 1.

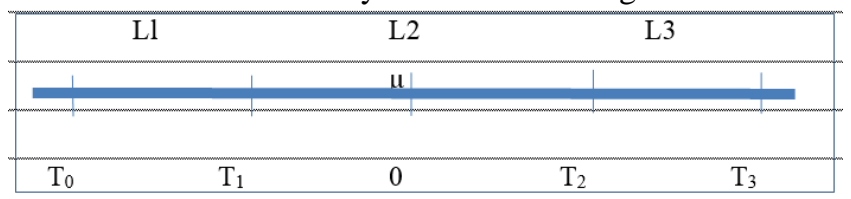

Figure 1. Event Study Timeline Series

Description:

$\mu=0$ as event date

$\mu=\mathrm{T} 1+1 \mathrm{~s} / \mathrm{d} \mu=\mathrm{T} 2$ represents event window

$\mu=\mathrm{T} 0+1 \mathrm{~s} / \mathrm{d} \mu=\mathrm{T} 1$ represents estimation window

$\mu=\mathrm{T} 2+1 \mathrm{~s} / \mathrm{d} \mu=\mathrm{T} 3$ represents post-event window

$\mathrm{L} 1=\mathrm{T} 1-\mathrm{T} 0$ denotes the length of estimation window

$\mathrm{L} 2=\mathrm{T} 2-\mathrm{T} 1$ denotes the length of event window

$\mathrm{L} 3=\mathrm{T} 3-\mathrm{T} 2$ denotes the length of post-event window

According to McWilliams \& Siegel (1997), a long event window distance will cause two problems in its practice: first, it will reduce the strength of the statistical test toward the $\mathrm{Zt}$ value, and then this reduction will lead errors in drawing conclusions about the significance of the event. A short event window will capture the significant effect of the event. The second problem is that it will be difficult to isolate the event window from the confounding effect. Phase 5, eliminate or adjust companies that already experienced other relevant events during the event window. At this phase, it has been concluded that the characteristics of the sample, the stocks that are actively traded during the observation period. Phase 6, calculate the abnormal return during the event window and test its significance.

\section{Methodology}

This study belongs to deductive research, which aims to test hypothesis through testing the theory application in certain circumstances. The test result is used as a basis to draw the conclusion, whether it supports or rejects hypothesis from the theoretical study. The form of this research is an event study, which studies the market reaction to an event whose information is published as an announcement (Jogiyanto, 2003).

The objects in this study were 45 companies whose stocks were registered in LQ45 members in Indonesia Stock Exchange during the October $4^{\text {th }}, 2016$ - December $4^{\text {th }}, 2016$ period. LQ45 was one of the leading indexes in Indonesia Stock Exchange since the selection process considers the liquidity factor, market capitalization, fundamental performance, and stock trading patterns. Thus, the selection of LQ45 Index was expected to represent more accurate research results through the expansion of research objects. 
The stock samples in the population were determined by population criteria, such as stocks should always be actively traded every day during the study period. Based on these criteria, 40 companies were chosen as the research objects.

The demonstration was occurred on November $4^{\text {th }}, 2016$, thus, the study period was set for 60 trading days since October, $4^{\text {th }}$ to December, $4^{\text {th }}$ 2016. It is chosen because such time span is considered short enough. According to Setyawasih (2007), if the distance of the event window is too long, it will cause two problems. First, it will reduce the strength of statistical tests and lead errors in drawing conclusions about the significance of the event. Second, the longer the period, the more difficult it will be to isolate the event window from the confounding effect. The type of data used in this study was a quantitative data obtained through secondary data sources, namely the official website of Indonesia Stock Exchange www.idx.co.id. The variables to be studied can be defined as follows:

First, Abnormal Return. Abnormal return is the difference between the actual rates of return that occurs with the investor expected return rate. The existence of an abnormal return indicates that an announcement or event has content information (Jogiyanto, 2003). Second, Trading volume activity (TVA) shows stock trading activity and reflects how active and liquid a stock is traded in the stock market. TVA calculations were performed by comparing the number of stocks of the traded company with the total number of outstanding stocks during the study period (Eduardus, 2001).

\section{Result and Discussion}

The data analysis of Stock Volume Trading Activity and Stock Abnormal Return used Repeated ANOVA statistical parametric test. It set $95 \%$ confidence level $(\alpha=0.05)$ for the results of the study. ANOVA could be done if the data meet the assumptions of normality and homogeneity variables, so the data normality was tested using Kolmogorov - Smirnov method. This method was used to analyze whether the data had a normal distribution or not. Next, the researcher used Levene testing to test the data homogeneity.

The result of the data normality testing of Stock Trading Volume Activity and Stock Abnormal Return can be seen in Table 1. The hypothesis of the data was determined through the value of the obtained significance, where $\mathrm{H}_{0}$ was a normal distributed data. $\mathrm{H}_{0}$ would be rejected when the significance score is $<0.05$. Based on the results of the analysis, it could be obtained that the data of Stock Volume Trading Activity and Stock Abnormal Return scores Asymp.Sig 0.000 and 0.000. Since the significance value was $>0.05$, so $\mathrm{H}_{0}$ was accepted, meaning that all of the data were abnormal distribution.

Table 1. NPar Tests

\begin{tabular}{ccc}
\hline Variable & Significance & Description \\
\hline Volume Trading & 0.000 & Abnormal distribution \\
\hline Abnormal Return & 0.000 & Abnormal distribution \\
\hline Source: Processed Data & &
\end{tabular}

The data hypothesis was determined by the significance score. In this case, $\mathrm{H}_{0}$ was the data that met the homogeneous assumptions. $\mathrm{H}_{0}$ would be rejected when the significance score was $<0.05$. Based on the results of homogeneity test, data of Stock Volume Trading Activity and Stock Abnormal Return were 0.994 and 0.996 significance score. The results indicated that the data variant of Stock Trading Activity and Stock Abnormal Return is homogeneous; the detailed description was presented in Table 2.

Table 2. Homogeneous Assumptions Testing

\begin{tabular}{ccc}
\hline Variable & Significance & Description \\
\hline Volume Trading & 0.994 & Homogeneous \\
\hline Abnormal Return & 0.996 & Homogeneous \\
\hline Source: Processed Data & &
\end{tabular}

The data met the homogeneity assumption but did not pass the normality testing, so it could not be continued by using Repeated ANOVA test. However, it was still continued by using Repeated ANOVA test since the researchers would like to see the difference the phenomenon of November, $4^{\text {th }} 2016$. The test result of Repeated ANOVA showed the difference on the Stock Volume Trading Activity on before, during and after the demonstration. The detailed results of Repeated ANOVA can be seen in Table 3: 
Table 3. Stock Volume Trading Activity Analysis Results

\begin{tabular}{|c|c|c|c|c|}
\hline Volume Trading & Mean +/- SD & & Significance & Description \\
\hline Before & $\begin{array}{l}57097012.85 \\
190598248.6\end{array}$ & $+/-$ & \multirow{3}{*}{0.006} & \multirow{3}{*}{ Significantly Different } \\
\hline During & $\begin{array}{l}57370393.04 \\
188104260.1\end{array}$ & $+/-$ & & \\
\hline After & $\begin{array}{l}66559756.49 \\
195614758.0\end{array}$ & $+/-$ & & \\
\hline
\end{tabular}

Source: Processed Data

Based on Table 3, the significance score result was 0.006. It was smaller than the 0.05 alpha score, so it can be said that there was a significant difference between the Stock Trading Activity Volume on before, during and after the event. To know the partial difference of Stock Volume Trading Activity, we used pairwise comparison Bonferroni test in Table 4.

According to the Partial Test, Stock Volume Trading Activity increased but not significant since before and during the event, the significance value was 1,000 meaning that it was larger than the alpha = 0.05. Therefore, there was no significant difference between the Stock Volume Trading Activity before and during the demonstration. However, the Stock Volume Trading Activity condition during and after the event experienced a significant increase with 0.008 significant score, smaller than alpha score $=0.05$. In this case, it can be stated that there was a significant difference between Stock Trading Activity Volume during and after the November $4^{\text {th }}, 2016$ demonstration.

Table 4. Differences in Stock Volume Trading Activity in before, during, and after the events

\begin{tabular}{|c|c|c|c|}
\hline \multicolumn{2}{|c|}{ Stock Volume Trading Activity } & Significance & Description \\
\hline \multirow{2}{*}{ Before } & During & 1.000 & Not significantly different \\
\hline & After & 0.127 & Not significantly different \\
\hline \multirow{2}{*}{ During } & Before & 1.000 & Not significantly different \\
\hline & After & 0.008 & Significantly different \\
\hline \multirow{2}{*}{ After } & Before & 0.127 & Not significantly different \\
\hline & During & 0.008 & Significantly different \\
\hline
\end{tabular}

Source: Processed Data

The condition of before and after the event also did not have a significant difference, the significance score was 0.127 that was bigger than alpha $=0.05$. The detailed description of the Stock Volume Trading Activity can be seen in Figure 2:

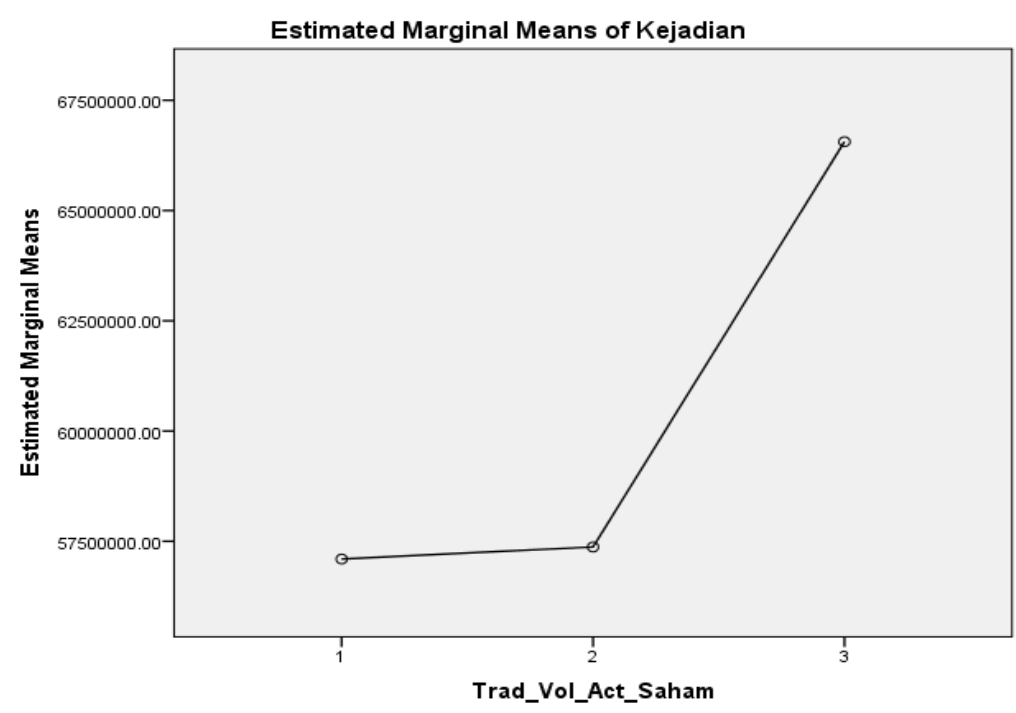

Figure 2. Stock Volume Trading Activity conditions before, during, and after the November, $4^{\text {th }} 2016$ demonstration.

Description:

$1=$ Before November, $4^{\text {th }} 2016$ demonstration 
$2=$ During November, $4^{\text {th }} 2016$ demonstration

$3=$ After November, $4^{\text {th }} 2016$ demonstration

The results of Repeated ANOVA test showed the difference between Stock Abnormal Return on before, during and after the event. The results can be seen in Table 5.

Table 5. Results of Stock Abnormal Return Analysis

\begin{tabular}{lcll}
\hline Abnormal Return & Mean +/- SD & Significance & Description \\
\cline { 1 - 2 } Before & $7696.285+/-12035.813$ & & Significantly \\
During & $7612.474+/-11990.675$ & 0.030 & different \\
\cline { 1 - 2 } After & $7516,186+/-11911.361$ & &
\end{tabular}

Sources: Processed Data

Based on Table 5, the significance score was 0.030 , smaller than the 0.05 alpha score. It can be said that there was a significant difference between Stock Abnormal Return on before, during and after the event. To find out the partial difference of Stock Abnormal Return on before, during and after the conditions of the event, the researchers used pairwise comparison Bonferroni test in Table 6:

Table 6. Differences of Stock Abnormal Return on before, during, and after the events

\begin{tabular}{llll}
\hline Stock Abnormal Return & & Significance & Description \\
\hline \multirow{2}{*}{ Before } & During & 0.024 & Significantly different \\
\cline { 2 - 4 } & After & 0.235 & Not significantly different \\
\hline \multirow{2}{*}{ During } & Before & 0.024 & Significantly different \\
\cline { 2 - 4 } & After & 0.733 & Not significantly different \\
\hline \multirow{2}{*}{ After } & \multirow{2}{*}{ Before } & 0.235 & Not significantly different \\
\cline { 2 - 4 } & & & Not significantly different \\
\hline
\end{tabular}

Source: Processed Data

According to the Partial Test, Stock Abnormal Return significantly decreased since before and during the event with 1,000 significant score. It was larger than the alpha $=0.024$, meaning that there was a significant difference between Stock Abnormal Return on before and during the event. Stock Abnormal Return during demo November 4, 2016 to the condition after the demo 4 November 2016 also experienced a significant decrease but the significance value of 0.235 was greater than alpha $=0.05$. It meant that there was no significant difference between Stock Abnormal Return on during and after the event. The condition on before and after the event also did not have a significant difference with the significance of 0.773 , bigger than alpha $=0.05$. The description of the condition of Return on before, during and after the event can be seen in Figure 3:

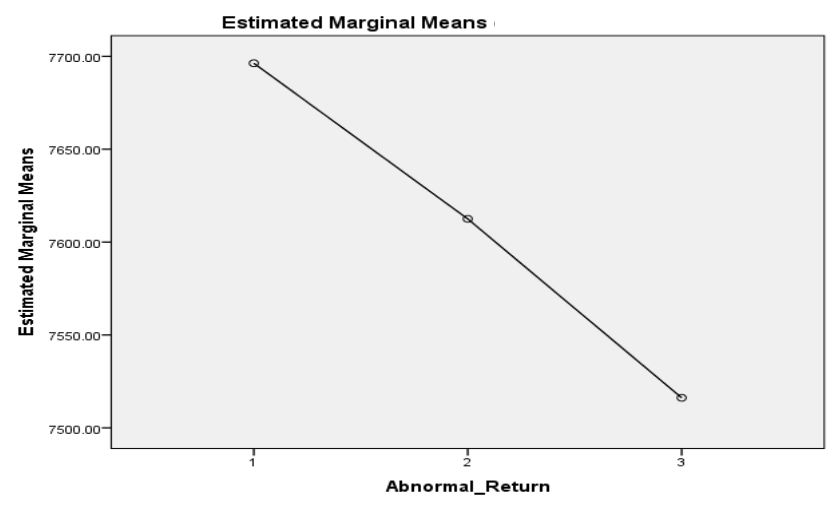

Figure 3. Stock Return condition at the conditions before, during, and after the events

Description:

$1=$ before the November, $4^{\text {th }} 2016$ demonstration

$2=$ during the November, $4^{\text {th }} 2016$ demonstration

$3=$ after the November, $4^{\text {th }} 2016$ demonstration 
The results in this study indicate that political events can trigger stock market movements. In this case study research there is a decrease in stock returns and also an increase in trading volume, namely the number of shares being sold. this indicates a negative sentiment for the November 4 demonstration. The reaction is in line with the results of research by Bittlingmayer (1998) stated that political events are more clearly the source of volatility, and the results support the view that the relationship between volatility and output ref lects the joint effects of political factors. Similar research by Kim, H. Y., \& Mei, J. P. (2001) employs a components-jump volatility filter to investigate the possible market impact of political risk. The filter operates by identifying jump return dates, which are then associated with political events, allowing us to measure the market return and volatility effects of political announcements. Our empirical results show that political developments in Hong Kong have a significant impact on its market volatility and return. The results have some interesting implications for option pricing and political risk management.

\section{Conclusions, suggestions and limitations}

The result of this research can be concluded that the November, 4th 2011 demonstration affect the Volume Trading Activity and Stock Return. So there is a reaction on Stock Market toward November, 4th 2011 demonstration. The reactin is seen by trading volume activity had an upward trend, while stock return was vice versa. Precisely, Trading Volume Activity before-during the events did not show much growth, so there was no significant difference. While Trading Volume Activity during-after event experienced much rise, to show a significant difference.

Stock returns overall decreased, stock return on before-after the event partially did not decrease much that there was no significant difference. While the stock return before-after events experienced a lot of decrease, so there were significant differences. It can be concluded that LQ45 stock market was a strong market.

The fluctuation in society can indirectly affect the economic condition of a country. Specifically in this study, it showed that there was an influence on the stock market in Indonesia although in very small impact. Governments can manage in such a way to regulate economic and financial mechanisms in order to create a strong market. Thus, if there was social upheaval in society, the fundamentals of the state's finances will have no effect on the country.

This study can be further analyzed by examining the occurrence changes. The reaction of the event was on the Trading Volume Activity and the stakeholders' movement toward the action. Dealing with the stock return, it can be further investigated which companies in the LQ45 list during the event that experienced many decrease in stock return.

Limitation in this study was the timeline research that was too long. Thus, there are so many amounts of data can cause bias in this study. It was because this research analyzed very sensitively and rapidly changing information.

\section{Acknowledgement}

The research team expressed their gratitude to the Center for Economic, Business and Entrepreneurship Development (PPEBK) Faculty of Economics \& Business University of Muhammadiyah Malang which has provided support financially for this research.

\section{References}

Bittlingmayer, G. (1998). Output, stock volatility, and political uncertainty in a natural experiment: Germany, 1880-1940. The Journal of Finance, 53(6), 2243-2257.

Chau, F., Deesomsak, R., \& Wang, J. (2014). Political uncertainty and stock market volatility in the Middle East and North African (MENA) countries. Journal of International Financial Markets, Institutions and Money, 28, 1-19.

Devi Kusuma Wardani. (2004). Analisis Reaksi Pasar Modal Indonesia Sebagai Dampak dari Peristiwa Politik (Political Event) Pemilu 5 April 2004 pada Saham LQ-45.Skripsi. Jurusan Manajemen Fakultas Ekonomi Universitas Brawijaya Malang.

Eduardus Tandelilin. (2001). Analisis Investasi dan Manajemen Portofolio. Yogyakarta: BPFE.

Imam Ghozali. (2006). Aplikasi Analisis Multivariate dengan Program SPSS. Semarang: Badan Penerbit Universitas Diponegoro.

Jogiyanto. (2003). Teori Portofolio dan Analisis Investasi Edisi 3. Yogyakarta: BPFE.

Kim, H. Y., \& Mei, J. P. (2001). What makes the stock market jump? An analysis of political risk on Hong Kong stock returns. Journal of International Money and Finance, 20(7), 1003-1016. 
MacKinley, A. Craig. (1997). Event Studies in Economics and Finance. Journal of Economic Literature, Vol. XXXV (March 1997), Hal 13-39.

Maria Qifthiyah Alkaff. (2010). Pengaruh Pemilihan Presiden RI Tahun 2009 Terhadap Harga Saham Dan Volume Perdagangan Saham Perusahaan di Bursa Efek Indonesia (Event Study Pada Saham Anggota JII). Skripsi, Jurusan Akuntansi Fakultas Ekonomi Universitas Pembangunan Nasional "Veteran" Jawa Timur.

Marwan Asri Suryawijaya dan Faizal Arief Setiawan. (1998). Reaksi Pasar Modal Indonesia Terhadap Peristiwa Politik Dalam Negeri (Event Study pada Peristiwa 27 Juli 1996). KELOLA, Vol. VII No. 18 Hal 137-153.

Mochamad Zaqi. (2006). Reaksi Pasar Modal Indonesia Terhadap Peristiwa-Peristiwa Ekonomi dan Peristiwa-Peristiwa Sosial Politik Dalam Negeri (Studi pada Saham LQ-45 BEJ Periode 19992003). Tesis. Program Studi Magister Manajemen Program Pascasarjana Universitas Diponegoro Semarang.

Neni Meidawati dan Mahendra Harimawan. (2004). Pengaruh Pemilihan Umum Legislatif Indonesia Tahun 2004 Terhadap Return Saham dan Volume Perdagangan Saham LQ-45 di PT. Bursa Efek Jakarta (BEJ). Sinergi, Vol. 7 No. 1 2004, Hal 89-100

Wahyu Estining Rahayu. (2007). Reaksi Pasar Modal Terhadap Pengumuman Perombakan (Reshuffle) Terbatas Kabinet Indonesia Bersatu (Studi Empiris pada Perusahaan-Perusahaan yang Terdaftar di Bursa Efek Jakarta). Sinergi, Vol. 9 No. 2, Juni 2007, Hal 129-142. 